\title{
Feature
}

\section{Oncogenic drivers and immunotherapy: staying one step ahead of lung cancer}

Jane de Lartigue, $\mathrm{PhD}$

L

ung cancer remains the single biggest cause of cancer-related mortality, responsible for major breakthroughs in the treatment of the most common form - non-small-cell lung cancer (NSCLC) - have been heralded in the past decade, many challenges remain. Here, we discuss how attempts to address these challenges are the driving force behind a continuing paradigm shift in lung cancer treatment.

\section{EGFR and ALK: a model of targeted drug development}

The majority of newly diagnosed lung cancers are NSCLC, and about half of those are adenocarcinomas (Figure 1). ${ }^{2}$ Over the past decade there has been a significant evolution in the understand- ing and treatment of lung adenocarcinoma, mostly stemming from a greater appreciation of the distinct pathologies and unique molecular signatures of these tumors. Genomic characterization of the molecular signatures has led to the identification of numerous key genetic alterations that drive lung cancer. The dependency of lung tumors on these genetic drivers has enabled the pharmacological development of targeted therapies that exploit this vulnerability.

The best studied of these drivers are mutations in the epidermal growth factor receptor (EGFR) gene and rearrangements in the anaplastic lymphoma kinase $(A L K)$ gene, both of which encode proteins that are members of the receptor tyrosine kinase family - the master regulators of cellular signaling that regulate an array of intracellular signaling cascades. ${ }^{3}$ The 2 most common EGFR alterations

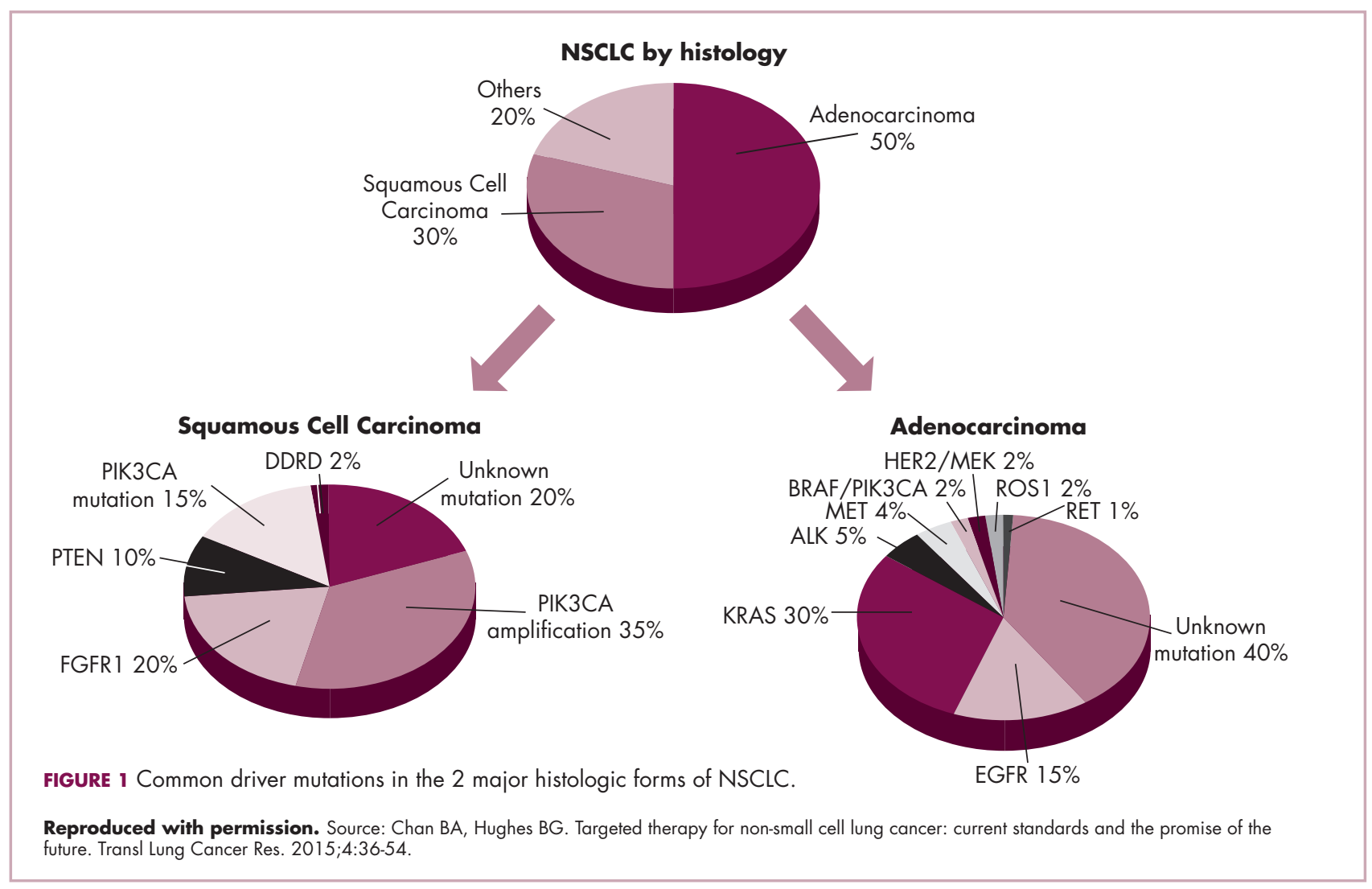

JCSO 2015;13:260-267. @2015 Frontline Medical Communications. DOI 10.12788/icso.0146. 


\begin{tabular}{|c|c|c|}
\hline Drug & Manufacturer & Status of ongoing clinical testing \\
\hline Erlotinib (Tarceva) & OSI & $\begin{array}{l}\text { FDA approved in locally advanced or metastatic disease after failure of } \\
\text { prior chemotherapy (2004), for maintenance therapy in patients with } \\
\text { locally advanced or metastatic disease after first-line chemotherapy } \\
\text { (2010), for first-line treatment of metastatic disease in patients with EGFR } \\
\text { mutations (2013) } \\
\text { Ongoing clinical trials include: Phase } 3 \text { in patients with surgically resected } \\
\text { disease (NCT02193282) }\end{array}$ \\
\hline Gefitinib (Iressa) & AstraZeneca & $\begin{array}{l}\text { FDA approved (2003) } \\
\text { Approval withdrawn and indication limited to patients who previously } \\
\text { benefited from gefitinib (2005) } \\
\text { Use discontinued in the US (2011) } \\
\text { Ongoing clinical trials include: } \\
\text { Phase } 3 \text { vs vinorelbine/platinum therapy as adjuvant treatment in stage } \\
\text { II-IIIA disease with EGFR mutations (ADJUVANT; NCTO1405079) } \\
\text { Phase } 3 \text { intercalated for induction therapy in combination with chemother- } \\
\text { apy in patients with EGFR mutations (Neolntercal; NCTO2326285) } \\
\text { Phase } 3 \text { as intercalating and maintenance therapy vs chemotherapy } \\
\text { (NCT01404260) }\end{array}$ \\
\hline Afatinib (Gilotrif) & Boehringer Ingelheim & $\begin{array}{l}\text { FDA approved as first-line treatment for patients with metastatic disease } \\
\text { with EGFR alterations (2013) } \\
\text { Ongoing clinical trials include: } \\
\text { Phase } 3+/ \text { - cetuximab in patients with EGFR-positive newly diagnosed } \\
\text { stage IV or recurrent disease (NCTO2438722) } \\
\text { Phase } 3 \text { in advanced disease with EGFR mutations (NCTO1953913) }\end{array}$ \\
\hline Rociletinib (CO-1686) & Clovis & $\begin{array}{l}\text { FDA breakthrough therapy designation for second-line treatment of } \\
\text { T790M-mutant NSCLC patients (2014); to be submitted for NDA in July. } \\
\text { Ongoing trials include: } \\
\text { Phase } 3 \text { vs single-agent chemotherapy in patients with EGFR-mutant dis- } \\
\text { ease who failed prior therapy with at least one TKI and platinum doublet } \\
\text { chemotherapy (TIGER-3; NCTO2322281) } \\
\text { Phase } 2 \text { as second-line therapy in patients with EGFR-mutant disease } \\
\text { (TIGER-2; NCTO2147990) } \\
\text { Phase } 2 \text { vs erlotinib in patients with EGFR-mutant disease (TIGER-1; } \\
\text { NCTO2186301) }\end{array}$ \\
\hline AZD9291 & AstraZeneca & $\begin{array}{l}\text { Ongoing trials include: } \\
\text { Phase } 3 \text { vs gefitinib or erlotinib in locally advanced or metastatic disease } \\
\text { (FLAURA; NCTO2296125) } \\
\text { Phase } 3 \text { vs platinum-based doublet chemotherapy in locally advanced or } \\
\text { metastatic disease (AURA3; NCT02 151981) } \\
\text { Phase } 3 \text { + anti-PDLI antibody MEDI4736 vs monotherapy in EGFR } \\
\text { T790M mutation-positive disease after prior TKI therapy (CAURAL; } \\
\text { NCTO2454933) }\end{array}$ \\
\hline HM61713 & Hanmi & $\begin{array}{l}\text { Ongoing trials include: } \\
\text { Phase } 2 \text { in patients with EGFR-positive disease (NCT02444819) }\end{array}$ \\
\hline
\end{tabular}

FDA, US Food and Drug Administration; EGFR, epidermal growth factor receptor; NDA, new drug application; NSCLC, non-small-cell lung cancer TKI, tyrosine kinase inhibitor; PDL-1, programmed cell death ligand-1 NSCLC, non-small-cell lung cancer

found in lung cancer patients are exon 19 deletions and L858R missense substitutions. ${ }^{4-6}$ Meanwhile, $A L K$ alterations most commonly involve a chromosomal inversion, in which chromosome 2 (on which the $A L K$ gene is located) is broken and part of the DNA reinserts into the chromosome in the reverse orientation, the result being a fusion between the $A L K$ gene and the echinoderm microtubule associated protein like 4 (EML4) gene. ${ }^{7}$ Both EGFR mutations and $A L K$ rearrangements ultimately lead to the inap- propriate activation of the kinase activity of these receptors. The development of small molecule inhibitors of EGFR and ALK designed to suppress their activation have subsequently revolutionized the treatment of patients with lung adenocarcinoma whose tumors harbor these genetic changes. For patients with EGFR mutations, erlotinib ${ }^{8}$ and, more recently, afatinib ${ }^{9}$ have been approved in the United States. Gefitinib was initially approved, but approval was withdrawn and use in the US 


\section{Feature}

A

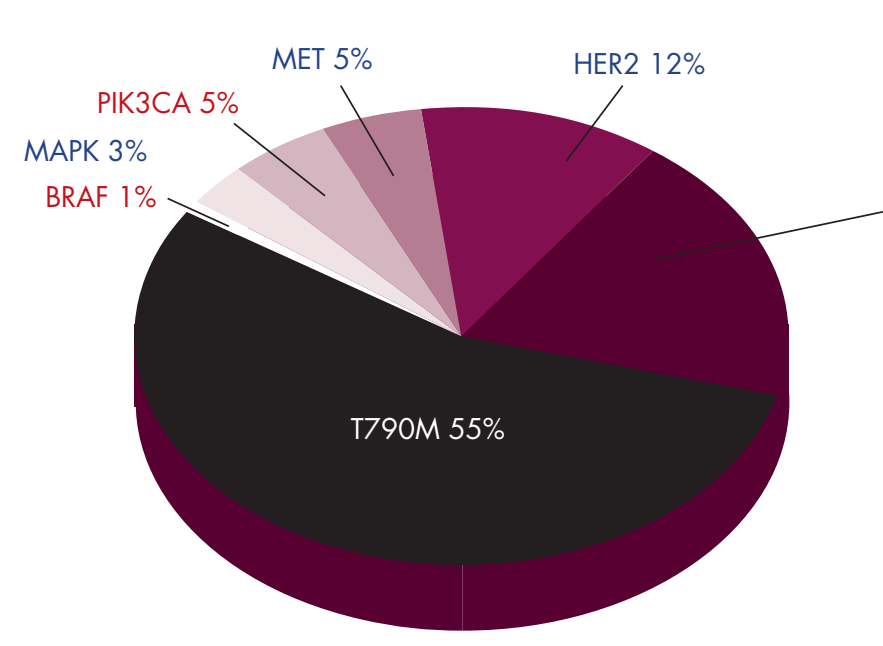

B

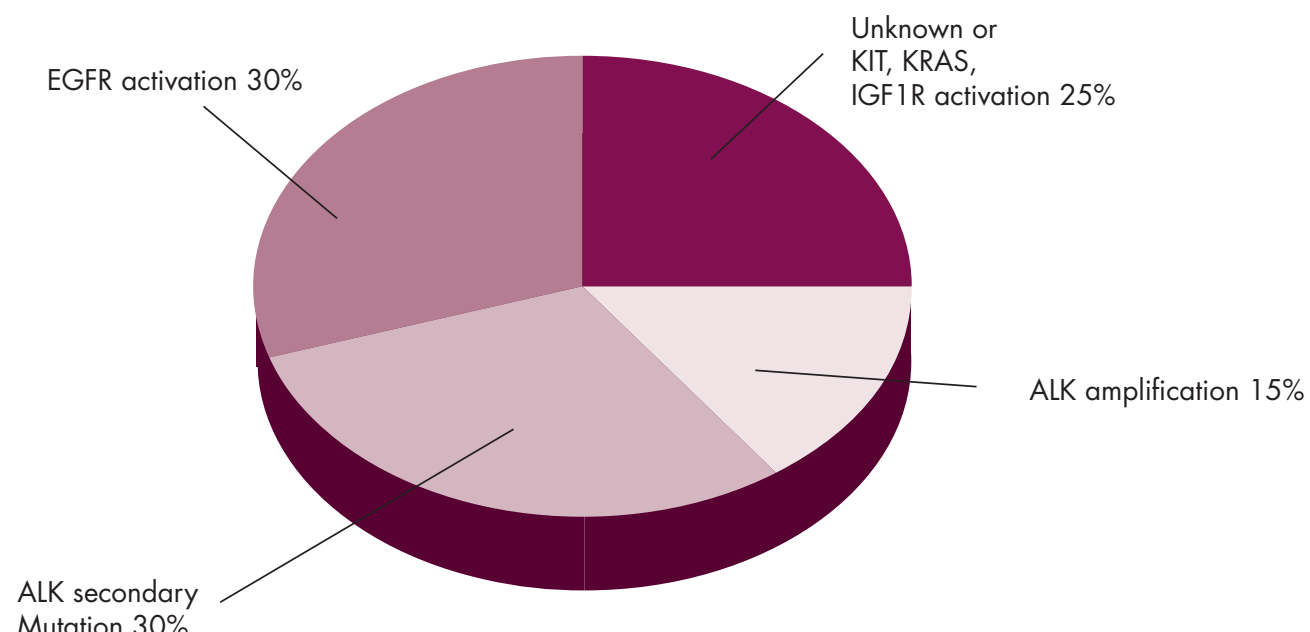

Mutation 30\%

FIGURE 2 Mechanisms of resistance to EGFR and ALK inhibition in NSCLC

Summary of some of the reported mechanisms of resistance to first-generation (a) EGFR and (b) ALK tyrosine kinase inhibitors. Red text represents mutations, blue text represents amplifications. $\uparrow E$, increased expression; $\downarrow E$, loss of expression; $\uparrow A$, increased activation; $\uparrow R$, up-regulation; $\downarrow R$, down-regulation.

Reproduced with permission. Adapted from: Stewart EL, et al. Known and putative mechanisms of resistance to EGFR targeted therapies in NSCLC patients with EGFR mutations - a review. Transl Lung Cancer Res. 2015;4:67-81; and Isozaki H, et al. Mechanisms of acquired resistance to ALK inhibitors and the rationale for treating ALK-positive lung cancer. Cancers. 2015;7:763.

discontinued after it failed to improve survival in subsequent clinical trials, ${ }^{10}$ although numerous clinical trials are still ongoing in more select patient populations (Table 1). EGFR tyrosine kinase inhibitors (TKIs) have demonstrated superior response rates, progression-free survival (PFS), and quality of life compared with chemotherapy in patients with metastatic disease that is EGFR mutation positive. ${ }^{11-16}$ None of the studies have demonstrated an overall survival (OS) benefit as yet, though this has been attributed to extensive cross-over after progression. ${ }^{17}$ $\uparrow E:$ KDM5, FGF2

FGFR 1, AXL, ROR 1 or Notch-1

$\uparrow A: N F \kappa B$. Wnttankyrase- $\beta$-catentin, JAK2, or FEGFR

$\uparrow R:$ ADAM17

$\downarrow R$ : DAPK or NF 1

$\downarrow E$ : IGF binding proteins

EMT/SCLC

transformation

Gain of stem-cell like properties

Tumor stromal factors

For patients with ALK rearrangements, the small-molecule TKI crizotinib was awarded accelerated regulatory approval in 2011 for the treatment of patients with metastatic disease, a mere 4 years after the discovery of the ALK-EML4 fusion in NSCLC patients. Full FDA approval followed in 2013, based on the demonstration of improved PFS compared with chemotherapy, coupled with a favorable toxicity profile, in the phase 3 PROFILE-1007 trial. ${ }^{18,19}$ The rapid clinical development of crizotinib has been heralded as a model of successful and efficient drug development in a molecularly targeted patient population.

In December 2014, AstraZeneca announced that the ongoing phase 3 PROFILE-1014 trial, in which criztonib is being evaluated as first-line therapy compared with platinum-pemetrexed chemotherapy in treatment-naïve patients, had met its primary endpoint of improved PFS (10.9 vs 7 months, respectively), with no unexpected safety issues, suggesting that crizotinib may become gold standard treatment for all lines of therapy in $A L K$-positive NSCLC. ${ }^{20}$

\section{Gatekeepers of resistance}

Depsite the success of EGFR- and ALK-targeted therapies in lung cancer, the significant responses observed with first and even second-generation (in the case of EGFR) 


\begin{tabular}{|c|c|c|}
\hline Drug & Manufacturer & Status of ongoing clinical testing \\
\hline Crizotinib (Xalkori) & Pfizer & $\begin{array}{l}\text { FDA approved in ALK-positive metastatic disease (2013) } \\
\text { Ongoing clinical trials include: } \\
\text { Phase } 3 \text { in patients with ALK-positive stage Ib-llla disease that has been surgi- } \\
\text { cally resected (NCTO2201992) } \\
\text { Phase } 3 \text { vs alectinib in treatment-naïv ALK-positive advanced disease (ALEX; } \\
\text { NCT02075840) } \\
\text { Phase } 3 \text { vs chemotherapy in previously untreated ALK-positive East Asian } \\
\text { patients (NCTO1639001) }\end{array}$ \\
\hline Ceritinib (Zykadia) & Novartis & $\begin{array}{l}\text { FDA approved in ALK-positive metastatic disease after treatment with crizotinib } \\
\text { (2014) } \\
\text { Ongoing clinical trials include: } \\
\text { Phase } 3 \text { vs chemotherapy in ALK-positive patients previously treated with plati- } \\
\text { num doublet chemotherapy and crizotinib (NCTO18281 12) } \\
\text { Phase } 3 \text { vs chemotherapy in previously untreated patients with ALK-positive dis- } \\
\text { ease (NCT01828099) }\end{array}$ \\
\hline Alectinib & Roche & $\begin{array}{l}\text { Ongoing clinical trials include: } \\
\text { Phase } 3 \text { expanded access study for patients with ALK-rearranged disease after } \\
\text { progression on or intolerance to prior ALK inhibitor therapy } \\
\text { Phase } 3 \text { vs crizotinib in treatment-naive ALK-positive disease (ALEX; } \\
\text { NCT02075840) }\end{array}$ \\
\hline Brigatinib (AP261 13) & Ariad & $\begin{array}{l}\text { Ongoing clinical trials include: } \\
\text { Phase } 2 \text { in ALK-positive locally advanced or metastatic disease that progressed } \\
\text { on crizotinib therapy (ALTA; NCTO2094573) } \\
\text { Phase } 1 / 2 \text { in patients with advanced malignancies including ALK-positive } \\
\text { NSCLC (NCTO1449461) }\end{array}$ \\
\hline$X-396$ & Xcovery & $\begin{array}{l}\text { Phase } 1 / 2 \text { first-in-human study in advanced solid tumors, including NSCLC } \\
\text { (NCT01625234) }\end{array}$ \\
\hline
\end{tabular}

agents is, all too often, not durable. The development of acquired resistance to these agents is all but inevitable, and patients typically progress within 1-2 years of initiating TKI therapy.

Analysis of tumors that progress have revealed a large number of molecular mechanisms underlying resistance (Figure 2), including secondary mutations in the therapeutic target and activation of alternate signaling pathways that can bypass the target. By far the most common mechanism of resistance to EGFR TKIs in lung cancer, found in more than half of all cases, is the secondary EGFR mutation, T790M. T790M is dubbed a "gatekeeper" mutation because it affects a threonine residue in the EGFR protein that controls access to the hydrophobic pocket within the active site of the kinase. The point mutation changes the threonine to a bulkier amino acid that disrupts the TKI's ability to bind to its target and/or alters the affinity of the kinase for adenosine triphosphate (ATP), ${ }^{2,22,23}$

Another common mechanism of resistance to EGFR TKIs is amplification of $M E T$, which activates the downstream phosphatidylinositol-3-kinase (PI3K)-Aktmammalian target of rapamycin (mTOR) pathway independently of EGFR activation. ${ }^{22}$ Resistance to ALK TKIs is likewise complex, including an analogous gatekeeper mutation (L1196M), though this is far less common than T790M in EGFR TKI-treated patients. Indeed, although secondary ALK mutations and activation of EGFR are common, there is no single predominant mechanism of resistance to ALK TKIs. ${ }^{2,24-26}$

Efforts to overcome resistance have driven the development of second- and third-generation TKIs, which are designed to be more potent, irreversible inhibitors of the kinase or to specifically inhibit a particular mutant form, such as T790M. Most advanced in development are the EGFR TKIs rociletinib (CO-1686) and AZD9291, and the ALK TKIs alectinib, brigatinib (AP26113), and ceritinib (Table 2).

Rociletinib and AZD9291 are designed to inhibit the T790M and L858R EGFR mutant forms as well as EGFR TKI-sensitizing mutants, while sparing wild-type $E G F R .^{27,28}$ Enrollment is currently underway for a phase 3 trial of rociletinib in patients who failed prior TKI and chemotherapy, the TIGER-3 trial (NCT02322281), in addition to various other earlier stage trials.

The results of one such trial were presented at the 2015 annual meeting of the American Society of Clinical 
Oncology in Chicago. TIGER-X is a phase $1 / 2$ study of rociletinib in heavily pretreated patients with T790M-mutant EGFRpositive NSCLC. A $60 \%$ overall response rate $(\mathrm{ORR})$ and $90 \%$ disease control rate (DCR) were observed in patients with centrally confirmed tissue T790M positivity who were treated at a recommended dose of $500 \mathrm{mg}(\mathrm{n}=48)$. Across all dose groups ( $\mathrm{n}$ = 243), ORR was $53 \%$ and DCR was $85 \%$. Median PFS in patients without a history of central nervous system (CNS) metastases $(n=163)$ was 10.3 months. Responses were durable and the toxicity profile of rociletinib was tolerable. Of note is that about one-third of T790M-negative patients also responded, which could not be explained by retreatment effect. ${ }^{29}$

Rociletinib received breakthrough therapy designation from the FDA in May 2014 for second-line treatment of T790Mmutant NSCLC patients and data from the TIGER-X trial will be combined with data from the TIGER-2 study for the new drug application (NDA) package that is expected to be submitted in July.

AZD9291 is currently being evaluated in three phase 3 trials (FLAURA, AURA3, and CAURAL), as well as a number of phase 1 and 2 studies. Investigators recently published the results from the first-in-human AURA study of AZD9291 in which 253 patients with radiologically documented disease progression after prior EGFR TKI therapy received AZD9291 at doses of $20-240 \mathrm{mg}$ once daily. ORR was $51 \%$ overall, but $61 \%$ in 127 patients with confirmed T790M mutation, compared with $21 \%$ for those without, and median PFS was 9.6 months in T790Mpositive patients. The most common adverse events were diarrhea, rash, nausea and decreased appetite. The results of an expansion cohort from this study were also presented at ASCO. An ORR of $81 \%$ was reported in treatment-naive patients with T790M-mutant NSCLC. ${ }^{30}$

In addition to being evaluated as monotherapy, the safety profile of AZD9291 suggested that it may be amenable to combination therapy and several combination trials are ongoing. Preliminary data from the multi-arm phase 1b TATTON study of AZD9291 in combination with the programmed cell death-ligand 1 (PD-L1) inhibitor MEDI4736, the MET inhibitor AZD6094 or the MEK inhibitor selumetinib in patients with advanced EGFRmutant NSCLC were also presented at ASCO. All 3 combinations were escalated to their phase 2 monotherapy doses and, in the 42 patients enrolled to date, there have been 3 partial responses (PRs) in the MEDI4736 arm, 2 PRs in the AZD6094 arm and 2 PRs in the selumetinib arm, with favorable toxicity profiles. ${ }^{31}$

Similar to these novel EGFR TKIs, the second-generation ALK TKIs ceritinib, brigatinib, and alectinib have all demonstrated inhibitory activity against resistant mutant forms of ALK, including L1196M, G1269Y, and S1206Y. ${ }^{32}$ In April 2014, ceritinib became the first drug to gain accelerated regulatory approval for the treatment of patients with metastatic NSCLC following crizotinib treatment, based on the demonstration of response rates of over $50 \%$ and a 7.4-month median duration of response. ${ }^{33,34}$ Alectinib and brigatinib are hot on its heels and both have been given breakthrough therapy designation. Numerous studies for both agents were presented at ASCO, including preliminary data from a phase $1 / 2$ study of brigatinib that showed promising antitumor activity in ALK-positive NSCLC patients, with and without prior crizotinib. ${ }^{35}$ 
TABLE 3 Clinical evaluation of targeted therapies in SCLC

\begin{tabular}{|c|c|c|c|}
\hline Drug & Manufacturer & Mechanism of action & Status of ongoing clinical testing in SCLC \\
\hline $\begin{array}{l}\text { Nintedanib } \\
\text { (BIBF1120) }\end{array}$ & Boehringer Ingelheim & Multikinase inhibitor & Phase 2 in platinum-sensitive disease (NCT02152059) \\
\hline $\begin{array}{l}\text { Pazopanib } \\
\text { (Votrient) }\end{array}$ & GlaxoSmithKline & Multikinase inhibitor & $\begin{array}{l}\text { Phase } 2 \text { as maintenance therapy (NCT01797874) } \\
\text { Phase } 2 \text { in relapsed/refractory disease (NCT01713296) }\end{array}$ \\
\hline $\begin{array}{l}\text { Ganetespib } \\
\text { (STA-9090) }\end{array}$ & Synta & Hsp90 inhibitor & Phase $1 / 2+$ doxorubicin (NCT02261805) \\
\hline $\begin{array}{l}\text { Navitoclax } \\
\text { (ABT-263) }\end{array}$ & AbbVie & Bcl-2 inhibitor & Phase 1/2 + trametinib (NCT02079740) \\
\hline OMP-59R5 & OncoMed & Notch $2 / 3$ inhibitor & $\begin{array}{l}\text { Phase } 1 / 2 \text { + etoposide and platinum therapy in extensive } \\
\text { stage disease (PINNACLE; NCTO1859741) }\end{array}$ \\
\hline $\begin{array}{l}\text { Roniciclib } \\
\text { (BAY1000394) }\end{array}$ & Bayer & $\begin{array}{l}\text { Cyclin dependent kinase } \\
\text { inhibitor }\end{array}$ & Phase 2 + chemotherapy (CONCEPT-SCLC; NCT02161419) \\
\hline $\begin{array}{l}\text { Veliparib } \\
\text { (ABT-888) }\end{array}$ & AbbVie & PARP inhibitor & $\begin{array}{l}\text { Phase } 1+\text { carboplatin/etoposide in treatment-naïve exten- } \\
\text { sive stage disease (NCT02289690) }\end{array}$ \\
\hline $\begin{array}{l}\text { Ipilimumab } \\
\text { (Yervoy) }\end{array}$ & Bristol-Myers Squibb & CTLA-4 inhibitor & $\begin{array}{l}\text { Phase } 3 \text { + etoposide vs platinum therapy + etoposide vs } \\
\text { platinum therapy alone (NCTO1450761) } \\
\text { Phase } 2 \text { in limited disease (STIMULI; NCT02046733) } \\
\text { Phase } 2 \text { + carboplatin + etoposide in extensive stage dis- } \\
\text { ease (ICE; NCTO1331525) }\end{array}$ \\
\hline $\begin{array}{l}\text { Nivolumab } \\
\text { (Opdivo) }\end{array}$ & Bristol-Myers Squibb & PD-1 inhibitor & $\begin{array}{l}\text { Phase } 1 / 2 \text { as monotherapy or + ipilimumab } \\
\text { (NCTO1928394) }\end{array}$ \\
\hline
\end{tabular}

Hsp90, heat shock protein 90; Bcl-2, B-cell lymphoma 2; PARP, poly(ADP) ribose polymerase; CTLA-4, cytotoxic T-lymphocyte antigen-4; PD-1, programmed cell death-1

A common site of metastasis in patients with advanced NSCLC is the central nervous system (CNS), which can be particularly challenging to treat because many drugs have limited penetration of the CNS. The results of 2 trials presented at ASCO demonstrate the significant activity of alectinib in patients with CNS progression. In 69 patients who progressed on crizotinib, ORR was $47.8 \%$ and DCR was $79.7 \%$, and in patients with measurable CNS disease, ORR and DCR were $68.8 \%$ and $100 \%$, respectively. In a second trial of 122 patients who failed prior crizotinib therapy, ORR was $49.2 \%$ and DCR was $79.5 \%$, with an ORR of $55.9 \%$ in patients with baseline CNS progression, including 5 complete responses (CRs), and median PFS was 8.9 months. ${ }^{36,37}$ These data are to be submitted to the FDA as part of an NDA for alectinib.

\section{Immunotherapy: hope for more challenging forms of lung cancer}

Although rationally designed targeted therapies continue to improve outcomes for patients with lung adenocarcinoma, other forms of lung cancer have proven significantly more challenging. Both the squamous form of NSCLC and other histological subtypes of lung cancer, such as small-cell lung cancer (SCLC) - the most aggressive subtype - have not benefited from targeted therapies, despite initial promise and extensive investigation (Table 3).

Recently, findings from molecular profiling studies have begun to more clearly elucidate the molecular mechanisms underlying these tumor types and have highlighted their distinct and significantly more complex genetic signatures compared to non-squamous NSCLC, which may partly explain the limited success of targeted therapies tested to date. ${ }^{38-40}$

Immunotherapy has emerged as a novel treatment paradigm for the treatment of lung cancer and has enjoyed particular success in the treatment of squamous cell NSCLC. Early immunotherapeutic approaches had limited efficacy in the treatment of solid tumors such as lung cancer, but an increasing appreciation of the ability of tumors to suppress the immune response has led to the development of targeted immunotherapies that have catalogued a slew of remarkable results in solid tumors in the past few years.

Checkpoint proteins, which include the programmed cell death receptor 1 (PD-1) and its ligands (PD-L1 and PD-L2), act as the immune system's fail-safe mechanism, preventing damage to normal tissue by ensuring the cytotoxic $T$ cells are switched on at the appropriate time and are switched off when no longer needed. Cancer cells manipulate the expression of checkpoint proteins to suppress T-cell activity and down-regulate the antitumor immune response, thus checkpoint inhibitors were developed that 


\section{Feature}

\begin{tabular}{|c|c|c|}
\hline Drug & Manufacturer & Status of ongoing clinical testing \\
\hline Tremelimumab & AstraZeneca & $\begin{array}{l}\text { Ongoing clinical trials include: } \\
\text { Phase } 1 \text { + gefitinib (GEFTREM; NCT02040064) }\end{array}$ \\
\hline Ipilimumab (Yervoy) & Bristol-Myers Squibb & $\begin{array}{l}\text { Ongoing clinical trials include: } \\
\text { Phase } 3 \text { + paclitaxel and carboplatin (NCTO2279732) } \\
\text { Phase } 2+\text { ionizing radiation (NCTO2221739) } \\
\text { Phase } 1+\text { erlotinib or crizotinib in EGFR or ALK-positive disease } \\
\text { (NCT01998126) }\end{array}$ \\
\hline MEDI-4736 & AstraZeneca & $\begin{array}{l}\text { Ongoing clinical trials include: } \\
\text { Phase } 3+\text { /- tremelimumab vs standard of care (MYSTIC; NCTO2453282) } \\
\text { Phase } 3+\text { tremelimumab and as monotherapy (ARCTIC; NCTO2352948) }\end{array}$ \\
\hline Pembrolizumab (Keytruda) & Merck & $\begin{array}{l}\text { Ongoing clinical trials include: } \\
\text { Phase } 3 \text { vs platinum-based chemotherapy (KEYNOTE-024; NCT02142738) } \\
\text { Phase } 3 \text { vs platinum-based chemotherapy (KEYNOTE-042; NCTO2220894) }\end{array}$ \\
\hline Atezolizumab (MPDL3280A) & Roche & $\begin{array}{l}\text { Ongoing clinical trials include: } \\
\text { Phase } 3 \text { + cisplatin or carboplatin + pemetrexed (IMpower 110; } \\
\text { NCT02409342) } \\
\text { Phase } 3 \text { vs gemcitabine + cisplatin or carboplatin (IMpower } 111 \text {; } \\
\text { NCT02409355) } \\
\text { Phase } 3 \text { + carboplatin + pemetrexed +/- bevacizumab (IMpower150) } \\
\text { Phase } 3 \text { + carboplatin + nab-paclitaxel (IMpower130; NCTO2367781) } \\
\text { Phase } 3 \text { + carboplatin + paclitaxel or nab-paclitaxel (IMpower 131; } \\
\text { NCT02367794) }\end{array}$ \\
\hline Nivolumab (Opdivo) & Bristol-Myers Squibb & $\begin{array}{l}\text { FDA-approved for patients with advanced squamous NSCLC who pro- } \\
\text { gressed on or after platinum-based chemotherapy (2015) } \\
\text { Ongoing clinical trials include: } \\
\text { Phase } 3 \text { in previously treated patients (CheckMate 153; NCT02066636) } \\
\text { Phase } 3 \text { vs investigator's choice of chemotherapy as first-line therapy } \\
\text { (CheckMate026; NCT02041533) }\end{array}$ \\
\hline
\end{tabular}

could help overcome tumor-induced immunosuppression by augmenting the tumor-specific $\mathrm{T}$-cell response. ${ }^{41}$

A number of checkpoint inhibitors have been developed and are being evaluated in lung cancer (Table 4), but furthest along in clinical development is nivolumab. Nivolumab was granted accelerated approval for the treatment of patients with squamous NSCLC that has progressed on or after platinum-based chemotherapy in March 2015, following demonstration of a 3.2-month improvement in OS, marking a second approved indication for this drug. ${ }^{42}$

The FDA has also recently granted priority review to pembrolizumab for patients with advanced NSCLC across all histologies whose disease progressed after platinum-based chemotherapy, suggesting it may be joining nivolumab as an approved agent shortly (a final decision is expected in October 2015). Promising results from the phase 2 POPLAR study of another checkpoint inhibitor, atezolizumab (MPDL3280A), were presented at $\mathrm{ASCO}$; it was shown to double OS compared with docetaxel chemotherapy. ${ }^{43}$

\section{References}

1. Ferlay J, Soerjomataram I, Ervik M, et al. GLOBOCAN 2012 v1.0, Cancer incidence and mortality worldwide. IARC CancerBase No.
11. Lyon, France: International Agency for Research on Cancer. http://www.iarc.fr/en/publications/eresources/cancerbases/. Accessed June 1, 2015

2. Chan BA, Hughes BGM. Targeted therapy for non-small-cell lung cancer: current standards and the promise of the future. Transl Lung Cancer Res. 2015;4:36-54.

3. Somasundaram A, Socinski MA, Burns TF. Personalized treatment of EGFR mutant and ALK-positive patients in NSCLC. Expert Opin Pharmacother. 2014;15:2693-2708.

4. Yarden Y, Sliwkowski MX. Untangling the ErbB s network. Nat Rev Mol Cell Biol. 2001;2:127-137.

5. Jackman DM, Yeap BY, Sequist LV, et al. Exon 19 deletion mutations of epidermal growth factor receptor are associated with prolonged survival in non-small cell lung cancer patients treated with gefitinib or erlotinib. Clin Cancer Res. 2006;12:3908-3914.

6. Rosell R, Moran T, Queralt C, et al. Screening for epidermal growth factor receptor mutations in lung cancer. N Engl J Med. 2009;361:958-967.

7. Soda M, Choi YL, Enomoto M, et al. Identification of the transforming EML4-ALK fusion gene in non-small-cell lung cancer. $\mathrm{Na}$ ture. 2007;448:561-566.

8. National Cancer Institute. FDA approval for erlotinib hydrochloride. http://www.cancer.gov/about-cancer/treatment/drugs/fda-erlotinibhydrochloride. Updated July 3, 2013. Accessed June 1, 2015.

9. US Food and Drug Administration. Afatinib. http://www.fda.gov/ Drugs/InformationOnDrugs/ApprovedDrugs/ucm360574.htm. Updated July 12, 2013. Accessed June 1, 2015.

10. National Cancer Institute. FDA approval for Gefitinib. http://www. cancer.gov/about-cancer/treatment/drugs/fda-gefitinib. Reviewed 
January 18, 2011. Accessed June 1, 2015.

11. Zhou C, Wu YL, Chen G, et al. Erlotinib versus chemotherapy as first-line treatment for patients with advanced EGFR mutationpositive non-small-cell lung cancer (OPTIMAL, CTONG-0802): a multicenter, open-label, randomized, phase 3 study. Lancet Oncol. 2011;12:735-742.

14. Rosell R, Carcereny E, Gervais R, et al. Erlotinib versus standard chemotherapy for European patients with advanced EGFR mutation-positive non-small-cell lung cancer (EURTAC): a multicenter, open-label, randomized phase 3 trial. Lancet Oncol. 2012;13:239-46.

15. Sequist LV, Yang JC, Yamamoto N, et al. Phase III study of afatinib or cisplatin plus pemetrexed in patients with metastatic lung adenocarcinoma with EGFR mutations. J Clin Oncol. 2013;31:3327-3334.

16. Wu YL, Zhou C, Hu CP, et al. Afatinib versus cisplatin plus gemcitabine for first-line treatment of Asian patients with advanced nonsmall-cell lung cancer harbouring EGFR mutations (LUX-Lung 6): an open-label, randomized phase 3 trial. Lancet Oncol. 2014;15:213222

17. Lee CK, Brown C, Gralla RJ, et al. Impact of EGFR inhibitor in non-small-cell lung cancer on progression-free and overall survival: a meta-analysis. J Natl Cancer Inst. 2013;105:595-605.

18. US Food and Drug Administration. Crizotinib. http://www.fda.gov/ Drugs/InformationOnDrugs/ApprovedDrugs/ucm376058.htm. Updated November 21, 2013. Accessed June 1, 2015.

19. Shaw AT, Kim DW, Nakagawa K, et al. Crizotinib versus chemotherapy in advanced ALK-positive lung cancer. N Engl J Med. 2013;368:2385-2394.

20. Solomon BJ, Mok T, Kim DW, et al. First-line crizotinib versus chemotherapy in ALK-positive lung cancer. N Engl J Med. 2014;371:2167-2177.

21. Stewart EL, Tan SZ, Liu G, et al. Known and putative mechanisms of resistance to EGFR targeted therapies in NSCLC patients with EGFR mutations - a review. Transl Lung Cancer Res. 2015;4:67-81.

22. Yun CH, Mengwasser KE, Toms AV, et al. The T790M mutation in EGFR kinase causes drug resistance by increasing the affinity for ATP. Proc Natl Acad Sci USA. 2008;105:2070-2075.

23. Sun JM, Ahn MJ, Choi YL, et al. Clinical implications of T790M mutations in patients with acquired resistance to EGFR tyrosine kinase inhibitors. Lung Cancer. 2013;82:294-28.

24. Doebele RC, Pilling AB, Aisner DL, et al. Mechanisms of resistance to crizotinib in patients with ALK gene rearranged non-small cell lung cancer. Clin Cancer Res. 2012;18:1472-1482.

25. Katayama R, Shaw AT, Khan TM, et al. Mechanisms of acquired crizotinib resistance in ALK-rearranged lung cancers. Sci Transl Med. 2012;4:120ra17.

26. Kim S, Kim TM, Kim DW, et al. Heterogeneity of genetic changes associated with acquired crizotinib resistance in ALK-rearranged lung cancer. J Thorac Oncol. 2013;8:415-422.

27. Walter AO, Sijn RT, Haringsma HJ, et al. Discovery of a mutant-selective covalent inhibitor of EGFR that overcomes T790M-mediated resistance in NSCLC. Cancer Discov. 2013;3:1404-1415.

28. Finlay MR, Anderton M, Ashton S, et al. Discovery of a potent and selective EGFR inhibitor (AZD9291) of both sensitizing and
T790M resistance mutations that spares the wild type form of the receptor. J Med Chem. 2014;57:8249-8267.

29. Sequist LV, Goldman JW, Wakelee HA, et al. Efficacy of rociletinib (CO-1686) in plasma-genotyped T790M-positive non-small cell lung cancer (NSCLC) patients (pts). J Clin Oncol. 2015;33(suppl; abstr 8001).

30. Jänne PA, Yang JC, Kim D, et al. AZD9291 in EGFR inhibitorresistant non-small-cell lung cancer. N Engl J Med. 2015;372:16891699.

31. Oxnard GR, Ramalingam SS, Ahn M, et al. Preliminary results of TATTON, a multi-arm phase Ib trial of AZD9291 combined with MEDI4736, AZD6094, or selumetinib in EGFR-mutant lung cancer. J Clin Oncol. 33;2015(suppl; abstr 2509)

32. Toyokawa G, Seto T. Updated evidence on the mechanisms of resistance to ALK inhibitors and strategies to overcome such resistance: clinical and preclinical data. Oncol Res Treat. 2015;38:291-298.

33. Shaw AT, Kim DW, Mehra R, et al. Ceritinib in ALK-rearranged non-small-cell lung cancer. N Engl J Med. 2014;370:1189-1197.

34. U.S. Food and Drug Administration. Ceritinib. http://www.fda.gov/ Drugs/InformationOnDrugs/ApprovedDrugs/ucm395386.htm. Updated April 30, 2014. Accessed June 1, 2015.

35. Camidge DR, Bazhenova L, Salgia R, et al. Safety and efficacy of brigatinib (AP26113) in advanced malignancies, including ALK+ non-small-cell lung cancer (NSCLC). J Clin Oncol. 2015;33(suppl; abstr 8062).

36. Gandhi L, Shaw A, Gadgeel SM, et al. A phase II, open-label, multicenter study of the ALK inhibitor alectinib in ALK+ non-small-cell lung cancer (NSCLC) US/Canadian population who had progressed on crizotinib (NP28761). J Clin Oncol. 2015;33(suppl; abstr 8019).

37. Ou S, Ahn J, De Petris L, et al. Efficacy and safety of the ALK inhibitor alectinib in ALK+ non-small-cell lung cancer (NSCLC) patients who have failed prior crizotinib: an open-label, single-arm, global phase 2 study (NP28673). J Clin Oncol. 2015;33(suppl; abstr. 8008).

38. Scagliotti GV, Bironzo P, Vansteenkiste JF. Addressing the unmet need in lung cancer: the potential of immuno-oncology. Cancer Treat Rev. 2015;41:465-475.

39. Morabito A, Carillio G, Daniele G, et al. Treatment of small cell lung cancer. Crit Rev Oncol Hematol. 2014;91:257-270.

40. Umemura S, Tsuchibara K, Goto K. Genomic profiling of smallcell lung cancer: the era of targeted therapies. Jap J Clin Oncol. 2015;45:513-519.

41. Soria JC, Marabelle A, Brahmer JR, et al. Immune checkpoint modulation for non-small cell lung cancer. Clin Cancer Res. 2015;21:2256-2262.

42. Brahmer J, Reckamp KL, Baas P, et al. Nivolumab versus docetaxel in advanced squamous-cell non-small cell lung cancer. N Engl J Med. 2015: Epub ahead of print May 31, 2015; updated June 17, 2015. DOI: 10.1056/NEJMoa1504627.

43. Spira AI, Park K, Mazieres J, et al. Efficacy, safety and predictive biomarker results from a randomized phase II study comparing atezolizumab vs docetaxel in 2L/3L NSCLC (POPLAR). J Clin Oncol. 33, 2015(suppl; abstr. 8010). 